Regular article

\title{
Reduction of bromate in a biological activated carbon filter under high bulk dissolved oxygen conditions and characterization of bromate-reducing isolates
}

\author{
Juan Liu, Jianwei Yu, Dong Li, Yu Zhang, Min Yang*

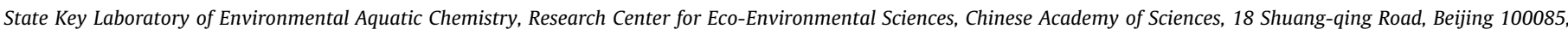 \\ China
}

\section{A R T I C L E I N F O}

\section{Article history:}

Received 25 January 2012

Received in revised form 10 March 2012

Accepted 2 April 2012

Available online 11 April 2012

\section{Keywords:}

Biofilters

Bromate-reducing bacteria

Dissolved oxygen

Biofilms

Biotransformation

Characterization

\begin{abstract}
A B S T R A C T
A biological activated carbon (BAC) filter was constructed using BAC from a pilot system that exhibited the ability to reduce bromate $\left(\mathrm{BrO}_{3}{ }^{-}\right)$and two $\mathrm{BrO}_{3}{ }^{-}$-reducing bacteria were isolated and characterized. The BAC filter could almost completely reduce $\mathrm{BrO}_{3}{ }^{-}(60 \mu \mathrm{gBr} / \mathrm{L})$ to bromide $\left(\mathrm{Br}^{-}\right)$at an influent dissolved oxygen (DO) level of approximately $8.0 \mathrm{mg} / \mathrm{L}$ and an empty bed contact time of $30 \pm 2 \mathrm{~min}$ using acetate as the electron donor shortly after the start-up. Phylogenetic analysis of the 16S rRNA gene sequences of a biological sample from the BAC filter showed that among the six detected orders, Rhodocyclalesand Burkholderiales-related microorganisms were dominant and Rhodocyclaceae- and Comamonadaceaerelated microorganisms may play a role in $\mathrm{BrO}_{3}-$ reduction. Two isolated pure cultures, i.e. Sphingomonas sp. 4721 and Deinococcus sp. 4710, exhibited the ability to reduce $\mathrm{BrO}_{3}{ }^{-}$in the presence of $\mathrm{NO}_{3}{ }^{-}$. The result of this study clearly indicated that $\mathrm{DO}$ was a competitor of $\mathrm{BrO}_{3}{ }^{-}$as an electron acceptor while $\mathrm{NO}_{3}{ }^{-}$was not. Construction of a BAC filter which could restrict oxygen transfer within a biofilm still remains to be a challenge.
\end{abstract}

(C) 2012 Elsevier B.V. All rights reserved.

\section{Introduction}

Bromate ion $\left(\mathrm{BrO}_{3}{ }^{-}\right)$, which is one of the major ozonation by-products in drinking water containing bromide ion $\left(\mathrm{Br}^{-}\right)$[1], has raised great concerns because of its carcinogenic potency in humans and the maximum contaminant level (MCL) in drinking water for $\mathrm{BrO}_{3}{ }^{-}$regulated by many countries is $10 \mu \mathrm{g} / \mathrm{L}$.

Two approaches to control $\mathrm{BrO}_{3}{ }^{-}$contamination in drinking water are recommended, including $\mathrm{BrO}_{3}{ }^{-}$minimization during ozonation and removal after formation. Several control technologies have been proposed for drinking water treatment to minimize the $\mathrm{BrO}_{3}{ }^{-}$formation during ozonation, such as $\mathrm{pH}$ depression, ammonia or hydrogen peroxide $\left(\mathrm{H}_{2} \mathrm{O}_{2}\right)$ addition [2,3]. However, only a partial reduction of $\mathrm{BrO}_{3}{ }^{-}$could be expected using these methods under practical operating conditions. On the other hand, it has been reported that $\mathrm{BrO}_{3}{ }^{-}$could be effectively reduced to $\mathrm{Br}^{-}$ by anaerobic mixed microbial cultures [4] or denitrifying bacteria [5-7]. However, these methods require almost complete removal of dissolved oxygen (DO) and nitrate $\left(\mathrm{NO}_{3}{ }^{-}\right)$from water, leading to the significant increase of treatment costs. Recently, some studies have shown that biological removal of $\mathrm{BrO}_{3}{ }^{-}$by biological activated carbon (BAC) filters could be achieved in the presence of low

\footnotetext{
* Corresponding author. Tel.: +86 10 62923475; fax: +86 1062923541 .

E-mail address: yangmin@rcees.ac.cn (M. Yang).
}

concentrations of $\mathrm{DO}$ and $\mathrm{NO}_{3}{ }^{-}$[8], whereas the removal of $\mathrm{BrO}_{3}{ }^{-}$ decreased with the increase of $\mathrm{DO}$ and $\mathrm{NO}_{3}{ }^{-}$concentrations $[9,10]$. The $\mathrm{NO}_{3}-$ levels in most surface source waters are relatively low. Therefore, a process sequence was proposed for biological $\mathrm{BrO}_{3}{ }^{-}$ reduction in which a DO reducing step was added before the BAC filters [9]. However, the BAC filters in our previous pilot study showed significant $\mathrm{BrO}_{3}{ }^{-}$reduction without taking any special measures to control the influent DO $(10-11 \mathrm{mg} / \mathrm{L})$ and $\mathrm{NO}_{3}{ }^{-}(1.5-4.4 \mathrm{mg} / \mathrm{L})$ when the biofilm of the BAC filter had formed after continuous operation for 5 months [11]. This result suggested that it may be possible to construct a $\mathrm{BAC}$ filter to biologically remove $\mathrm{BrO}_{3}{ }^{-}$without reducing $\mathrm{DO}$, which would be a significant advantage in $\mathrm{O}_{3}-\mathrm{BAC}$ process.

Furthermore, understanding the underlying mechanisms of $\mathrm{BrO}_{3}{ }^{-}$reduction would be very helpful for the removal of $\mathrm{BrO}_{3}{ }^{-}$ using BAC filters. Recently, fifteen $\mathrm{BrO}_{3}{ }^{-}$-reducing bacteria from different phylogenetic groups were acquired from different sources [8]. Some denitrifying organisms were reported to be able to reduce $\mathrm{BrO}_{3}{ }^{-}$[5]. In addition, it has been speculated that $\mathrm{NO}_{3}{ }^{-}$reductase, which catalyzes $\mathrm{NO}_{3}{ }^{-}$reduction, may also catalyze microbial $\mathrm{BrO}_{3}{ }^{-}$ reduction [10]. However, the mechanisms involved in biological $\mathrm{BrO}_{3}{ }^{-}$reduction are still not well understood.

The objectives of the current study focused on (i) confirming the possibility of biological $\mathrm{BrO}_{3}{ }^{-}$reduction using a BAC filter under high bulk DO conditions; (ii) identifying the major microbes responsible for $\mathrm{BrO}_{3}{ }^{-}$removal by constructing clone libraries for 
biological samples; (iii) isolating $\mathrm{BrO}_{3}{ }^{-}$-reducing bacteria from different BAC samples, comparing and investigating their $\mathrm{BrO}_{3}{ }^{-}$ reducing behaviors. The result of this study will be helpful for constructing and operating a $\mathrm{BAC}$ filter to remove $\mathrm{BrO}_{3}{ }^{-}$more effectively.

\section{Materials and methods}

\subsection{Chemicals and $\mathrm{BrO}_{3}{ }^{-}$-containing water preparation}

Potassium bromate $\left(\mathrm{KBrO}_{3}\right)$ and potassium bromide $(\mathrm{KBr})$ were guaranteed reagents and other chemicals used in the current study were analytical grade. Tap water $\left(\mathrm{pH} 7.5-7.7, \mathrm{NO}_{3}{ }^{-}=1.5-2.4 \mathrm{mg} / \mathrm{L}\right.$, $\mathrm{DO}=7.7-8.2 \mathrm{mg} / \mathrm{L}$ ) containing approximately $20 \mu \mathrm{g} / \mathrm{L}$ of $\mathrm{Br}^{-}$, spiked with $\mathrm{KBrO}_{3}(60 \mu \mathrm{g} / \mathrm{L}$ as $\mathrm{Br})$ was used as influent for the bench-scale experiment. Furthermore, $1 \mathrm{mg} / \mathrm{L}$ sodium acetate $\left(\mathrm{CH}_{3} \mathrm{COONa}\right)$ was added to the influent as exogenous carbon source.

\subsection{Experimental apparatus set-up}

The BAC sample (columnar type with a diameter of $1.5-2.0 \mathrm{~mm}$ and length of 3-5 mm; Shanxi Xinhua Activated Carbon Company) used for the experiment was obtained from our previous $\mathrm{O}_{3}$-BAC pilot system [11]. The operating result of the BAC pilot system is shown in Fig. S1. Two glass columns (inner diameter $=4.0 \mathrm{~cm}$ ) with a working volume of $450 \mathrm{~mL}$ were filled with the BAC samples above, and one of them was used as a control by sterilizing the BAC before filling $\left(121^{\circ} \mathrm{C}, 30 \mathrm{~min}, 102.9 \mathrm{kPa}\right.$ ). Peristaltic pumps (LongerPump, YZ1515x Bt00-300M) were used to maintain the empty bed contact time (EBCT) at $30 \pm 2 \mathrm{~min}$. The filters were maintained at room temperature $\left(25^{\circ} \mathrm{C}\right)$ and backwashed every 15 days, and the experiment was operated for 45 days.

\subsection{Phylogenetic analysis of biological samples of the BAC filter}

\subsubsection{DNA extraction of biological samples}

In order to investigate the change of microbes before and after the operation of bench-scale BAC system in the current study, two biological samples were used for DNA extraction. Sample A was the original BAC taken from the pilot-scale system, and sample B was from the backwashed water after the BAC filter had been operated for 45 days in the lab. $5 \mathrm{~g}$ BAC from sample A was collected into a $10-\mathrm{mL}$ of centrifuge tube and for sample $B$, the bacteria harvested by membrane filtration with $0.22-\mu \mathrm{m}$ filters (Millipore GSWP, Millipore, USA) were suspended in $10 \mathrm{~mL}$ physiological saline for DNA extraction. DNA from the two samples was extracted using a FastDNA SPIN kit for soil (MP Biomedicals, France) facilitated with a FastPrep-24 bead beater system (FastPrep-24, MP, USA), and then quantified using a Nanodrop 1000 spectrophotometer (Thermo Scientific, Wilmington, DE, USA) for denaturing gradient gel electrophoresis (DGGE) analysis and bacterial gene clone library construction.

\subsubsection{DGGE analysis and construction of bacterial gene clone libraries}

For DGGE analysis [12], the V3 region of the 16S rRNA gene was amplified with primers GC341f and 534r using touchdown PCR methods. In addition, almost the full-length of the 16S rRNA gene sequences were amplified to construct bacterial gene clone libraries using universal primers $27 \mathrm{f}$ and $1492 \mathrm{r}$ [13]. All of the primers used in the current study are listed in Table S1.

The procedures for DGGE analysis and construction of the bacterial clone libraries are detailed in the supporting information. The DNA sequences used for the construction of clone libraries were searched against the Ribosomal Database Project II (RDP II) release 9.49 and the GenBank database using the BLAST program [14]. Phylogenetic trees were constructed using MEGA version 4.0 by the neighbor-joining algorithm and the Jukes-Cantor distance estimation method with bootstrap analyses for 1000 replicates [15]. Sequences sharing 97\% or greater identity were grouped into the same operational taxonomic unit (OTU) using software MOTHUR [16]. Sixty 16S rRNA gene sequences were submitted to the GenBank database under the accession numbers HQ697371-HQ697431.

\subsection{Isolation of pure cultures}

Two BAC samples, i.e. one taken from a full-scale waterworks (the waterworks located in Zhejiang Province, and the ozone dose was between 1.0 and $2.5 \mathrm{mg} / \mathrm{L}$ with $\mathrm{Br}^{-}$ranging from 85 to $130 \mu \mathrm{g} / \mathrm{L}$ in source water) and the other from the original BAC taken from the pilot-scale system, were used to isolate $\mathrm{BrO}_{3}{ }^{-}$reducing bacteria. The BAC samples were put into glass beakers containing $50 \mathrm{~mL}$ phosphate buffer $(\mathrm{pH} 7.2)$ and oscillated with glass beads (diameter $=5.0 \mathrm{~mm}$ ) for $2 \mathrm{~h}$. The buffered solutions were then transferred into liquid mineral salts (MS) medium $(0.1 \mathrm{~g} / \mathrm{L}$ $\mathrm{Na}_{2} \mathrm{HPO}_{4}, 5 \mathrm{mg} / \mathrm{L} \mathrm{CaCl}, 0.005 \mathrm{mg} / \mathrm{L} \mathrm{CoCl} 2 \cdot 6 \mathrm{H}_{2} \mathrm{O}, 0.01 \mathrm{mg} / \mathrm{L} \mathrm{H}_{3} \mathrm{BO}_{3}$, $5 \mathrm{mg} / \mathrm{L} \mathrm{MgCl} 2 \cdot 7 \mathrm{H}_{2} \mathrm{O}, 0.3 \mathrm{mg} / \mathrm{L} \mathrm{MnCl}_{2} \cdot 4 \mathrm{H}_{2} \mathrm{O}, 0.01 \mathrm{mg} / \mathrm{L} \mathrm{ZnCl} 2 \cdot \mathrm{H}_{2} \mathrm{O}$, and $0.3 \mathrm{mg} / \mathrm{L} \mathrm{FeCl}_{2} \cdot 7 \mathrm{H}_{2} \mathrm{O} ; \mathrm{pH}$ 7.2) [5] for enrichment. After being autoclaved, the MS medium was poured into $300-\mathrm{mL}$ serum bottles. $\mathrm{KBrO}_{3}, \mathrm{CH}_{3} \mathrm{COONa}$ and ammonia chloride solutions were then added after filtration through a $0.22-\mu \mathrm{m}$ sterile filter. Thus, the MS medium for enrichment was obtained with $\mathrm{BrO}_{3}{ }^{-}$, acetate and ammonia at final concentrations of $1.0,20$ and $4.0 \mathrm{mg} / \mathrm{L}$, respectively. In addition, resazurin $(0.5 \mathrm{mg} / \mathrm{L})$ was added as an indicator to show the changes of the DO level.

After inoculation, the serum bottles were flushed with filtered nitrogen gas using a $0.22-\mu \mathrm{m}$ sterile filter to reduce the DO level in the medium, capped with a rubber stopper and then incubated at $25^{\circ} \mathrm{C}$ in the dark. Periodically, samples were collected from the bottles for the measurement of $\mathrm{BrO}_{3}{ }^{-}$and $\mathrm{Br}^{-}$concentrations. The cultures that exhibited $\mathrm{BrO}_{3}{ }^{-}$removal were transferred to fresh medium after being cultivated for 20 days. The enrichment cultures were transferred twice during the study.

At the end of the third generation of enrichment, bacterial purification was performed on $\mathrm{R}_{2} \mathrm{~A}$ medium plates after aerobic incubation for 3 days at $35^{\circ} \mathrm{C}$. The $\mathrm{R}_{2} \mathrm{~A}$ medium was developed for the enumeration of oligotrophic bacteria from potable water [17]. Two strains were obtained, of which strain Y (deposited in China General Microbiological Culture Collection Center, CGMCC, No. 4721) was from our BAC filter and strain R (CGMCC No. 4710) from the full-scale waterworks. The $\mathrm{BrO}_{3}{ }^{-}$-reducing behaviors of the isolates were evaluated using the MS medium with and without addition of $\mathrm{NO}_{3}{ }^{-}$and $\mathrm{SO}_{4}{ }^{2-}$ under an initial DO level below $1 \mathrm{mg} / \mathrm{L}$.

\subsection{Characterization of the isolates}

Micrographs of the isolates (named strains $\mathrm{Y}$ and $\mathrm{R}$, respectively) were taken using a scanning electron microscope (SEM) (S-3000N, Hitachi, Japan). The 16S rRNA nucleotide sequence data of the two strains were deposited in the GenBank database under the accession numbers JF710625 for strain Y and JF710626 for strain R.

\subsection{Analytical methods}

A Dionex ICS-1500 ion chromatography (IC) equipped with an IonPac analytical column (AS19, $4 \mathrm{~mm} \times 250 \mathrm{~mm}$ ) was used to determine the concentrations of $\mathrm{BrO}_{3}{ }^{-}, \mathrm{Br}^{-}, \mathrm{NO}_{3}{ }^{-}$and sulfate ion $\left(\mathrm{SO}_{4}{ }^{2-}\right)$ in the $\mathrm{BAC}$ filter samples and in the batch $\mathrm{BrO}_{3}{ }^{-}$reduction studies. A HQ Model 30d DO meter (HACH, USA) and a Delta Model $320 \mathrm{pH}$ meter (METTLER, Switzerland) was used to measure DO and pH, respectively. Samples for DOC analysis were filtered 


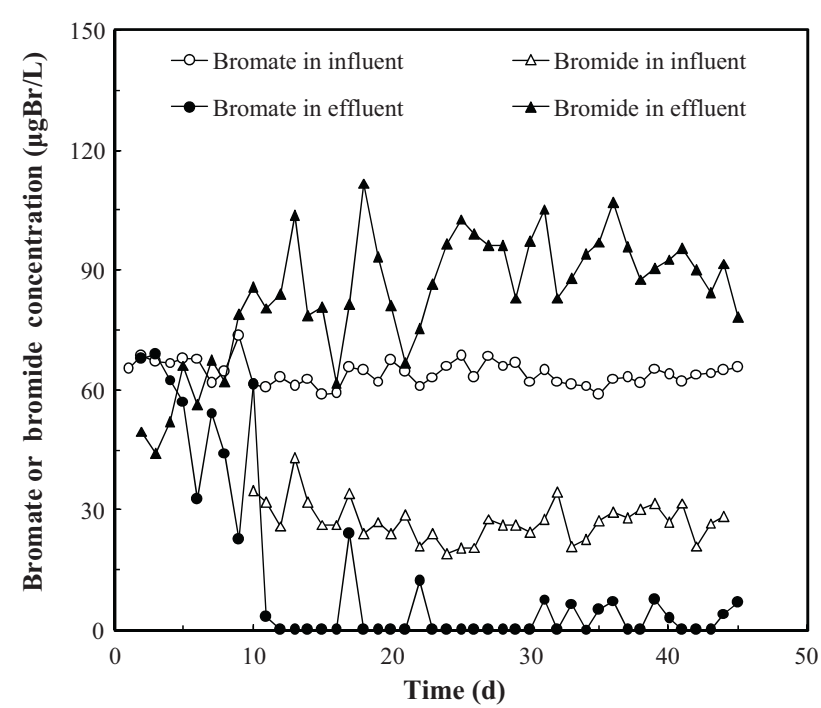

Fig. 1. Variations of $\mathrm{BrO}_{3}{ }^{-}$and $\mathrm{Br}^{-}$concentrations in the $\mathrm{BAC}$ filter. Data shown are means and the data standard deviation of all data points was below $5 \%$.

through $0.45-\mu \mathrm{m}$ nylon membranes and were analyzed by a total organic carbon (TOC) analyzer (Phoenix 8000, Tekmar Dohrmann Co., USA). All of the experiments were sampled and determined in duplicate. The data standard deviation of all data points was below $5 \%$.

\section{Results}

\section{1. $\mathrm{BrO}_{3}-$ removal performance of the $\mathrm{BAC}$ filter}

The changes of $\mathrm{BrO}_{3}^{-}$and $\mathrm{Br}^{-}$concentrations in the influent and effluent of the BAC filter are shown in Fig. 1. The effluent $\mathrm{BrO}_{3}{ }^{-}$ decreased quickly after the start-up of the filter, and was almost not detected in steady state (from day 11) except for occasional slight rebounds. Corresponding increase of $\mathrm{Br}^{-}$was observed simultaneously, of which the formed $\mathrm{Br}^{-}$in the effluent accounted for $92-100 \%$ of the added $\mathrm{BrO}_{3}{ }^{-}$(as $60 \mu \mathrm{g} / \mathrm{L} \mathrm{Br}$ ) in the influent during the continuous treatment. This indicates that almost all of the added $\mathrm{BrO}_{3}{ }^{-}$was reduced to $\mathrm{Br}^{-}$. In contrast, no $\mathrm{BrO}_{3}{ }^{-}$removal was observed in the control system (data not shown) in which the $\mathrm{BAC}$ had been sterilized before the start-up. This means that $\mathrm{BrO}_{3}{ }^{-}$ was biologically reduced to $\mathrm{Br}^{-}$by the $\mathrm{BAC}$ filter.

In addition, the variations of $\mathrm{DOC}, \mathrm{DO}$ and co-existing $\mathrm{NO}_{3}{ }^{-}$and $\mathrm{SO}_{4}{ }^{2-}$ during $\mathrm{BrO}_{3}{ }^{-}$reduction were also investigated. An average of $1.4 \mathrm{mg} / \mathrm{L} \mathrm{DOC}$ in the influent decreased to $1.0 \mathrm{mg} / \mathrm{L}$ in the effluent (Fig. S2). No apparent removal of $\mathrm{NO}_{3}{ }^{-}$or $\mathrm{SO}_{4}{ }^{2-}$ was observed (Fig. S3), whereas DO was reduced from approximately $8.0 \mathrm{mg} / \mathrm{L}$ in the influent to $5.5-6.0 \mathrm{mg} / \mathrm{L}$ in the effluent (Fig. S2). Thus, carbon source supplied in the influent was utilized as the electron donor for both the reduction of oxygen and $\mathrm{BrO}_{3}{ }^{-}$while the reduction of $\mathrm{NO}_{3}{ }^{-}$and $\mathrm{SO}_{4}{ }^{2-}$ did not occur.

\subsection{Characterization of bacterial community structures}

The comparison of the bacterial DGGE phylotype of samples A and B is demonstrated in Fig. 2. The two samples exhibited a low similarity (42.8\%). Bright DGGE bands were retrieved for sequence analysis, and only 5 sequences were acquired (Table S2). Samples A and B shared some common DGGE bands, such as bands 4 (Bradyrhizobium elkanii strain) and 5 (uncultured Acidobacteria). However, bands 1 (Janthinobacterium sp. 4-62) and 2 (uncultured Chloroflexi bacterium) were unique to sample $A$, and band 3 was (uncultured Rhodocyclaceae bacterium) unique to sample B.

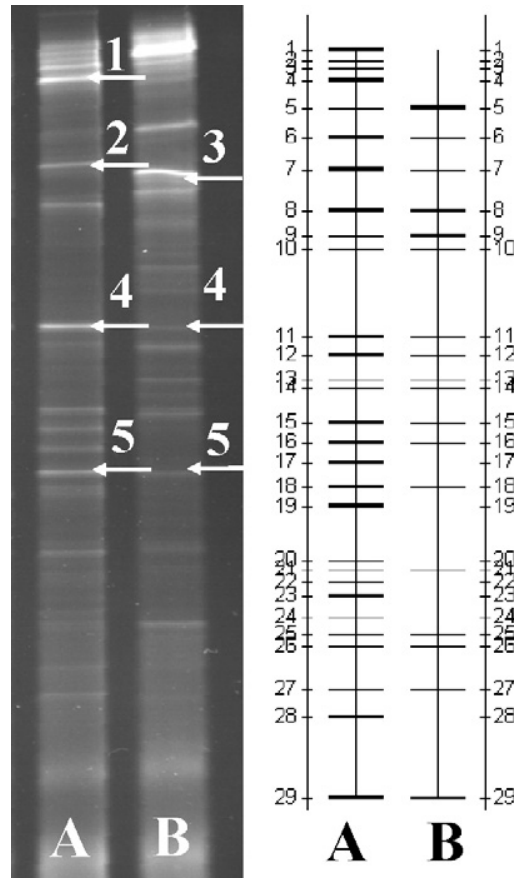

Fig. 2. DGGE profiles of partial $16 S$ rRNA fragments for samples A and B (sample A was from the initial bench-scale BAC filter in this study and sample B was from the backwashed water after the filter had been operating for 45 days).

Two 16S rRNA gene clone libraries were also constructed and the blast results are summarized in Table 1 . A total of 72 and 58 sequences were obtained and grouped into 37 and 23 OTUs for samples $A$ and $B$, respectively. Based on the blast results, phylogenetic trees for samples A and B were constructed as shown in Fig. S4.

Consistent with the DGGE results, the clone libraries of samples $A$ and $B$ were quite different from each other (Fig. S4). In clone library A, the majority (84.7\%) were affiliated with the phylum Proteobacteria, dominated by the classes Beta $(45.8 \%)$ and Alpha (36.1\%) (Table 1). The order Burkholderiales (37.5\% of all sequences) belonging to Betaproteobacteria and the order Rhizobiales (33.3\% of all sequences) belonging to Alphaproteobacteria were the two dominant bacterial groups. The clones belonging to the orders Burkholderiales and Rhizobiales were mainly grouped into the families Oxalobacteraceae (34.7\% of all sequences) and Bradyrhizobiaceae (9.7\% of all sequences), respectively. There were several clones with very high identity to Janthinobacterium sp. (GenBank accession no. D84590.2) and Variovorax sp. (GenBank accession no. D84645.2), which belong to the families Oxalobacteraceae and Comamonadaceae, respectively, in the order Burkholderiales.

In contrast, clone library B was more dominated by the phylum Proteobacteria (96.3\% of all sequences), particularly Betaproteobacteria (67.2\% of all sequences). Most of the clones in the class Betaproteobacteria fell into the orders Rhodocyclales (34.5\% of all sequences) and Burkholderiales (25.9\% of all sequences). Several sequences that are aligned with the genus Dechloromonas in the family Rhodocyclaceae were detected. Moreover, there were 14 sequences in sample B belonging to the family Rhodocyclaceae that showed very high identity (97-100\%) to the Betaproteobacteria that was able to reduce $\mathrm{NO}_{3}{ }^{-}$with p-xylene [18]. The major clones in the order Burkholderiales fell into the families Oxalobacteraceae (19.0\% of all sequences) and Comamonadaceae (6.9\% of all sequences), which were also found in clone library A. On the other hand, the clones belonging to the family Sphingomonadaceae ( $5.2 \%$ of all sequences) in the order Sphingomonadales, which have 
Table 1

Distribution of phylogenetic groups among bacterial 16S rRNA gene clone libraries for the two samples in the current study. ${ }^{\mathrm{a}}$

\begin{tabular}{|c|c|c|c|c|c|c|}
\hline \multirow[t]{2}{*}{ Phylum } & \multirow[t]{2}{*}{ Class } & \multirow[t]{2}{*}{ Order } & \multirow[t]{2}{*}{ Family } & \multirow[t]{2}{*}{ Genus } & \multicolumn{2}{|c|}{$\begin{array}{l}\text { No. of clones (no. of OTUs) } \\
\text { in sample }{ }^{b}\end{array}$} \\
\hline & & & & & A & B \\
\hline \multirow[t]{18}{*}{ Proteobacteria } & Alphaproteobacteria & Rhizobiales & Bradyrhizobiaceae & $\begin{array}{l}\text { Bradyrhizobium } \\
\text { Afipia }\end{array}$ & $7(2)$ & $1(1)$ \\
\hline & & & Hyphomicrobiaceae & Hyphomicrobium & $1(1)$ & \\
\hline & & & & Rhodoplanes & $1(1)$ & \\
\hline & & & Unclassified & & $15(4)$ & \\
\hline & & Sphingomonadales & Sphingomonadaceae & Blastomonas & & $3(1)$ \\
\hline & & Rhodobacterales & Rhodobacteraceae & Rhodobacter & & $2(1)$ \\
\hline & & Unclassified & & & $2(2)$ & $11(3)$ \\
\hline & Betaproteobacteria & Burkholderiales & Oxalobacteraceae & Unclassified & $25(6)$ & $11(3)$ \\
\hline & & & Comamonadaceae & Unclassified & $2(2)$ & $4(1)$ \\
\hline & & Rhodocyclales & Rhodocyclaceae & Dechloromonas & & $3(1)$ \\
\hline & & & & Zoogloea & & $1(1)$ \\
\hline & & & & Unclassified & & $14(5)$ \\
\hline & & & Unclassified & & & $2(2)$ \\
\hline & & Unclassified & & & $6(6)$ & $4(2)$ \\
\hline & Deltaproteobacteria & Syntrophobacterales & Syntrophaceae & Unclassified & $1(1)$ & \\
\hline & Gammaproteobacteria & Pseudomonadales; & Pseudomonadaceae & Pseudomonas & & $1(1)$ \\
\hline & & Unclassified & & & $1(1)$ & \\
\hline & Unclassified & & & & $1(1)$ & \\
\hline Planctomycetes & Planctomycetacia & Planctomycetales & Planctomycetaceae & Pirellula & $2(2)$ & \\
\hline \multirow[t]{2}{*}{ Acidobacteria } & Acidobacteria & Acidobacteriales & Acidobacteriaceae & Unclassified & $2(2)$ & \\
\hline & & Unclassified & & & $1(1)$ & $1(1)$ \\
\hline Bacteroidetes & Sphingobacteria & Sphingobacteriales & Unclassified & & $1(1)$ & \\
\hline Chloroflexi & Unclassified & & & & $1(1)$ & \\
\hline Unclassified & & & & & $3(3)$ & \\
\hline Total & & & & & $72(37)$ & $58(23)$ \\
\hline
\end{tabular}

a Classification was based on match results of RDP and the GenBank database.

b A blank indicates that no related clones were obtained.

been found in the treated water of several drinking water treatment plants using GAC filters [19], were not found in clone library A.

\subsection{Isolation and phylogenetic classification of the $\mathrm{BrO}_{3}{ }^{-}$-reducing bacteria}

Two $\mathrm{BrO}_{3}{ }^{-}$-reducing strains, i.e. Y (rod-shaped) and $\mathrm{R}$ (round), were obtained (Fig. S5). The 16S rRNA gene sequencing results showed that strain Y (GenBank accession no. JF710625) shared 98\% 16S rRNA gene sequence identity over 1466 bp with Sphingomonas sp. BBCT20 (GenBank accession no. DQ337548.1) affiliated with the family Sphingomonadaceae in the order Sphingomonadales, while strain R (GenBank accession no. JF710626) shared 95\% identity over 1476 bp with Deinococcus murrayi DSM 11303 (GenBank accession no. NR_026416.1) affiliated with the family Deinococcaceae in the order Deinococcales.

Both strains could reduce $\mathrm{BrO}_{3}{ }^{-}$to $\mathrm{Br}^{-}$in the MS medium with the removal rates of approximately $20 \mu \mathrm{g} /(\mathrm{Ld})$ and $8 \mu \mathrm{g} /(\mathrm{Ld})$ for strains $Y$ and $R$, respectively, as shown in Fig. 3. Similarly, the formation rates of $\mathrm{Br}^{-}$were $13.5 \mu \mathrm{g} /(\mathrm{Ld})$ and $5.8 \mu \mathrm{g} /(\mathrm{Ld})$, respectively. The presence of $\mathrm{NO}_{3}{ }^{-}(5 \mathrm{mg} / \mathrm{L})$ and $\mathrm{SO}_{4}{ }^{2-}(5 \mathrm{mg} / \mathrm{L})$ did not inhibit $\mathrm{BrO}_{3}{ }^{-}(1000 \mu \mathrm{g} / \mathrm{L})$ removal perceptibly (data not shown), and both ions were not removed by the strains.

To further elucidate the impacts of $\mathrm{DO}$ and $\mathrm{NO}_{3}{ }^{-}$on $\mathrm{BrO}_{3}{ }^{-}$ reduction, an experiment with higher levels of initial DO $(5.0 \mathrm{mg} / \mathrm{L})$ and $\mathrm{NO}_{3}{ }^{-}(22.1 \mathrm{mg} / \mathrm{L})$ was conducted with approximately $1000 \mu \mathrm{g} / \mathrm{L} \mathrm{BrO}_{3}{ }^{-}$and $200 \mathrm{mg} / \mathrm{L} \mathrm{CH}_{3} \mathrm{COONa}$ (Fig. 4). The two isolates began to reduce $\mathrm{BrO}_{3}{ }^{-}$when $\mathrm{DO}$ was exhausted with the removal rates of $20 \mu \mathrm{g} /(\mathrm{Ld})$ and $13 \mu \mathrm{g} /(\mathrm{Ld})$ for strains $\mathrm{Y}$ and $\mathrm{R}$, respectively, as shown in Fig. 4. The formation rates of $\mathrm{Br}^{-}$ were $12.5 \mu \mathrm{g} /(\mathrm{Ld})$ and $9.0 \mu \mathrm{g} /(\mathrm{Ld})$. However, no obvious removal of $\mathrm{NO}_{3}{ }^{-}$was observed for the duration of 40 days. This suggests that DO may be a competitor of $\mathrm{BrO}_{3}{ }^{-}$as an electron acceptor while $\mathrm{NO}_{3}{ }^{-}$was not.

\section{Discussion}

Although microbial reduction of $\mathrm{BrO}_{3}{ }^{-}$was identified nearly 20 years ago [5], $\mathrm{BrO}_{3}{ }^{-}$-reducing conditions in these studies were very strict. In most cases, almost complete removal of $\mathrm{DO}$ and $\mathrm{NO}_{3}{ }^{-}$was required, making it too expensive and complex to apply the process to drinking water treatment.

Kirisits and Snoeyink [9] reported that considerable $\mathrm{BrO}_{3}{ }^{-}$ reduction occurred in BAC filters even when $2 \mathrm{mg} / \mathrm{L}$ of DO and $5.1 \mathrm{mg} / \mathrm{L}$ of $\mathrm{NO}_{3}{ }^{-}$were present. However, the removal of $\mathrm{BrO}_{3}{ }^{-}$ in BAC filters decreased with the increase of $\mathrm{DO}$ and $\mathrm{NO}_{3}{ }^{-}$concentrations $[9,10]$. The two isolates acquired in the current study and some of the isolates acquired in the previous study [8] have exhibited $\mathrm{BrO}_{3}{ }^{-}$-removal capacity in the presence of $\mathrm{NO}_{3}{ }^{-}$(Fig. 4). Furthermore, in comparison with $\mathrm{DO}$, the $\mathrm{NO}_{3}{ }^{-}$levels are normally much lower in surface water. Hence, it is assumed that the presence of $\mathrm{NO}_{3}{ }^{-}$may not be a practical problem for $\mathrm{BrO}_{3}{ }^{-}$reduction.

In order to cancel the adverse effect of DO, removal of DO before BAC filtration was recommended to ensure sufficient $\mathrm{BrO}_{3}{ }^{-}$ removal [9]. The result in the current study, however, shows that almost complete $\mathrm{BrO}_{3}{ }^{-}$removal was achieved for an influent containing $\mathrm{BrO}_{3}^{-}$(as $60 \mu \mathrm{g} / \mathrm{L} \mathrm{Br}$ ) under high bulk DO condition $(8.0 \mathrm{mg} / \mathrm{L})$ when acetate was supplied as the electron acceptor (Figs. 1 and S2). The removal of $\mathrm{BrO}_{3}{ }^{-}$under saturated DO condition, which was formed during ozonation, was also observed in our previous pilot $\mathrm{O}_{3}$-BAC system (Fig. S1). An average $\mathrm{BrO}_{3}{ }^{-}$removal of $55 \%$ or $90 \%$ was achieved in BAC filters packed with granular or columnar activated carbon, respectively, even at a DO level of $10.0-11.0 \mathrm{mg} / \mathrm{L}$. This is the first report showing that remarkable biological $\mathrm{BrO}_{3}{ }^{-}$reduction could occur in a BAC filter in the presence of high bulk DO concentrations, which is very meaningful and important for the practical application of this process for $\mathrm{BrO}_{3}{ }^{-}$ removal.

$\mathrm{BrO}_{3}{ }^{-}$reduction tests using the pure cultures showed that the removal of $\mathrm{BrO}_{3}{ }^{-}$did not start until DO was depleted, indicating 

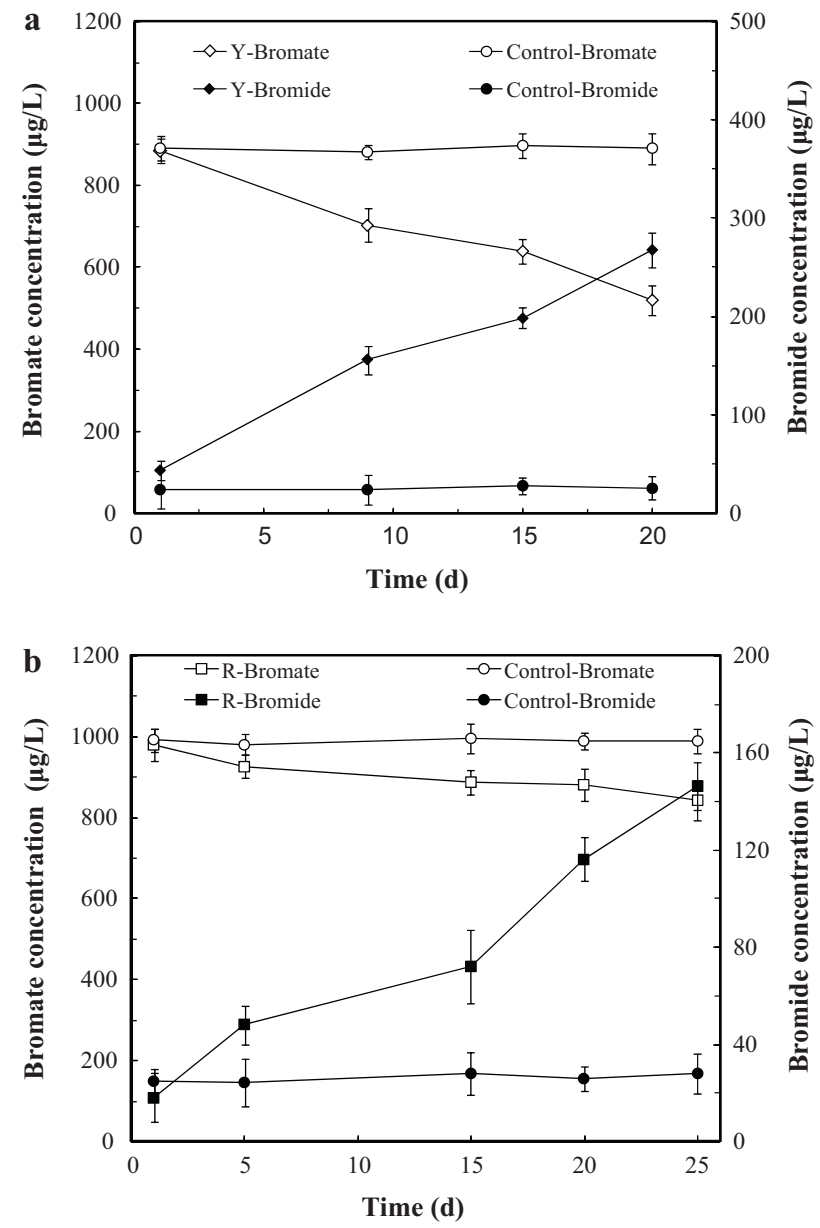

Fig. 3. Variations of $\mathrm{BrO}_{3}{ }^{-}$and $\mathrm{Br}^{-}$during the cultivation of the two strains (a: strain Y; b: strain R). Error bars indicate standard deviation (all below 5\%).

that DO was an inhibitor of $\mathrm{BrO}_{3}{ }^{-}$reduction. However, both the current study and our previous pilot study showed that the BAC filters could effectively remove $\mathrm{BrO}_{3}{ }^{-}$under the high bulk DO conditions. Hence, the formation of a DO gradient within the biofilm in the BAC filters may have made it possible for bacteria to reduce $\mathrm{BrO}_{3}{ }^{-}$[9]. As shown in Fig. S1, it was almost 5 months until the BAC filter was able to reduce $\mathrm{BrO}_{3}{ }^{-}$significantly, the time of which might be needed for the formation of biofilm. The quick start-up of the bench-scale BAC filter in the current study may be attributed to the direct use of the BAC from the pilot system. The formation of a DO gradient could be affected by many factors including biofilm thickness, micropore distribution of activated carbon, abundance of biodegradable organic compounds, etc., which will require further studies. Construction of a BAC filter which could restrict oxygen transfer within biofilm still remains to be a challenge.

Clone library analysis showed that the orders Burkholderiales and Rhizobiales constitute the two largest bacterial groups in sample A (the original BAC sample). Large numbers of bacteria affiliated to the orders Rhizobiales and Burkholderiales have previously been isolated from BAC filters [20]. Burkholderiales are believed to be important in the mineralization of dissolved organic matter in BAC, preferably using oxygen as an electron acceptor. Burkholderiales were also the second largest group in the clone library of sample B (the backwashed sample), which is understandable considering the fact that this group of bacteria has been found to be ubiquitous in BAC filters. It should be noticed that some clones affiliated into the family Comamonadaceae were detected in both samples, and it had been proved that some members of the family Comamonadaceae
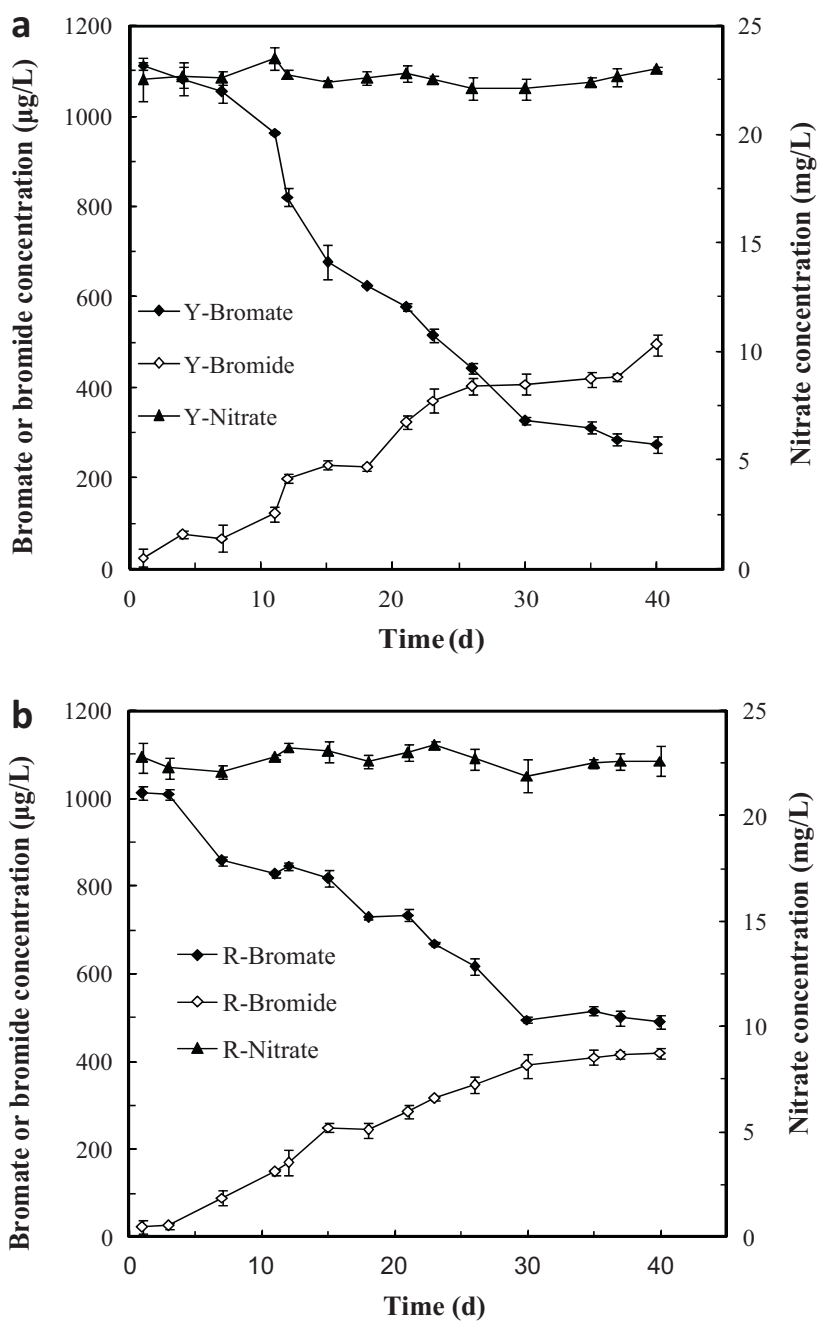

Fig. 4. Influence of $\mathrm{NO}_{3}{ }^{-}$added into the medium on $\mathrm{BrO}_{3}{ }^{-}$reduction performance by strain $\mathrm{Y}$ and R (a: strain Y; b: strain R). Error bars indicate standard deviation (all below 5\%).

are primary denitrifiers under anoxic conditions in activated sludge $[21,22]$. Therefore, the Comamonadaceae-related bacteria might be related with $\mathrm{BrO}_{3}{ }^{-}$reduction since it has been speculated that $\mathrm{NO}_{3}{ }^{-}$reductase may also catalyze microbial $\mathrm{BrO}_{3}{ }^{-}$reduction [10]. Although the Oxalobacteraceae-related bacteria were found abundant in both samples, and could be also detected in different aquatic environments $[23,24]$, their functions in $\mathrm{BrO}_{3}{ }^{-}$reduction process was still not clear.

On the other hand, the clones belonging to the order Rhodocyclales, which was not detected in sample A, became the largest bacterial group in sample $B$. Bacteria belonging to the order Rhodocyclales prefer oligotrophic conditions [25] and Rhodocyclus spp. are able to use (per)chlorate as the final electron acceptor [26,27]. Several sample B clones shared high identity with Rhodocyclaceae microorganisms that are highly enriched cultures of freshwater denitrifying bacteria [18]. With 95\% 16S rRNA gene sequence identity to Denitratisoma oestradiolicum [28], these denitrifying Rhodocyclaceae microorganisms could use (per)chlorate as electron acceptors with acetate as the electron donor. Some clones in sample B were similar to the highly enriched Betaproteobacteria, which is able to reduce $\mathrm{NO}_{3}{ }^{-}$with p-xylene [18]. It is known that p-xylene can be removed by microorganisms thriving under $\mathrm{NO}_{3}{ }^{-}$or $\mathrm{SO}_{4}{ }^{2-}$-reducing conditions. As shown in Table 1 , there were several sequences that are aligned with the genus Dechloromonas 
in the family Rhodocyclaceae. Dechloromonas sp. (GenBank accession no. AF170356.1) have been found to be associated with (per)chlorate reduction in previous studies [26,29,30]. In addition, two $\mathrm{BrO}_{3}{ }^{-}$-reducing isolated in a previous study were close neighbors with Dechloromonas spp. [8]. In general, the clones belonging to the order Rhodocyclales in general exhibit the common ability to utilize chlorate, perchlorate, $\mathrm{NO}_{3}{ }^{-}$or $\mathrm{BrO}_{3}{ }^{-}$as the electron acceptors. Therefore, the appearance of abundant Rhodocyclaceae- and Comamonadaceae-related bacteria in sample B suggests that these bacterial groups may have the ability to reduce $\mathrm{BrO}_{3}{ }^{-}$, considering the fact that $\mathrm{BrO}_{3}{ }^{-}$was one of the most abundant electron acceptor in the BAC filter.

However, the two $\mathrm{BrO}_{3}{ }^{-}$-reducing strains isolated in the current study, Sphingomonas sp. 4721 and Deinococcus sp. 4710, belong to the orders Sphingomonadales and Deinococcales, respectively. Both genera were different from the $\mathrm{BrO}_{3}{ }^{-}$-reducing bacteria reported in the previous studies [5,8,31]. One sequence in sample B had high identity to the order Sphingomonadales, but no Deinococcales-related sequence was detected in either sample. In addition, Sphingomonas spp. are found ubiquitously in the environment [32], possessing unique abilities to degrade refractory contaminants including a broad range of aromatic compounds $[33,34]$, whereas reports on the genus Deinococcus have been very limited [35]. Based on the fact that various $\mathrm{BrO}_{3}{ }^{-}$-reducing bacteria have been isolated $[5,8,31]$, it is possible that diverse phylogenetic groups revealed by the clone libraries were able to utilize $\mathrm{BrO}_{3}{ }^{-}$as an electron acceptor.

\section{Conclusions}

In this study, a bench-scale BAC filter was constructed using BAC from a previous pilot plant showing biological $\mathrm{BrO}_{3}{ }^{-}$reduction capacity. Almost complete $\mathrm{BrO}_{3}{ }^{-}$removal was achieved for an influent containing $\mathrm{BrO}_{3}{ }^{-}$(as $60 \mu \mathrm{g} / \mathrm{L} \mathrm{Br}$ ) under high bulk DO $(8.0 \mathrm{mg} / \mathrm{L})$ condition with sodium acetate used as the electron donor. For the first time, this study showed that almost complete biological $\mathrm{BrO}_{3}{ }^{-}$reduction could happen in a $\mathrm{BAC}$ filter without reducing the DO level, which is very important to apply the BAC process for the biological $\mathrm{BrO}_{3}{ }^{-}$removal. The Rhodocyclaceae- and Comamonadaceae-related microorganisms, some of which are close relatives of (per)chlorate-reducing or nitrate-reducing bacteria, might have played an important role in $\mathrm{BrO}_{3}{ }^{-}$reduction. The two $\mathrm{BrO}_{3}{ }^{-}$-reducing strains isolated in this study were Sphingomonas sp. 4721 belonging to the order Sphingomonadales and Deinococcus sp. 4710 belonging to the order Deinococcales, respectively. The two strains could selectively use $\mathrm{BrO}_{3}{ }^{-}$as the final electron acceptor even under the presence of $\mathrm{NO}_{3}{ }^{-}$. The result of this study clearly indicated that DO was a competitor of $\mathrm{BrO}_{3}{ }^{-}$as an electron acceptor while $\mathrm{NO}_{3}{ }^{-}$was not. Construction of a BAC filter which could restrict oxygen transfer within a biofilm still remains to be a challenge.

\section{Acknowledgments}

The research was supported by the Funds for the Creative Research Groups of China (NSFC No. 50921064) and Funds for Major Science and Technology Program for Water Pollution Control and Treatment (2008ZX07421-004 and 2009ZX07419-002). And the funds were used in the collection, analysis, and interpretation of data in current study.

\section{Appendix A. Supplementary data}

Supplementary data associated with this article can be found, in the online version, at http://dx.doi.org/10.1016/j.bej.2012.04.004.

\section{References}

[1] R. Butler, A. Godley, L. Lytton, E. Cartmell, Bromate environmental contamination: review of impact and possible treatment, Crit. Rev. Environ. Sci. Technol. 35 (2005) 193-217.

[2] U.V. Gunten, J. Hoigné, Bromate formation during ozonization of bromidecontaining waters: interaction of ozone and hydroxyl radical reactions, Environ. Sci. Technol. 28 (1994) 1234-1242.

[3] U. Pinkernell, U.V. Gunten, Bromate minimization during ozonation: mechanistic considerations, Environ. Sci. Technol. 35 (2001) 2525-2531.

[4] C.G.V. Ginkel, A.M.V. Haperen, B.V.D. Togt, Reduction of bromate to bromide coupled to acetate oxidation by anaerobic mixed microbial cultures, Water Res. 39 (2005) 59-64.

[5] W. Hijnen, R. Voogt, H.R. Veenendaal, H.v.d.Jagt, D.v.d. Kooij, Bromate reduction by denitrifying bacteria, Appl. Environ. Microbiol. 61 (1995) 239-244.

[6] W.A.M. Hijnen, R. Jong, D.v.d. Kooij, Bromate removal in a denitrifying bioreactor used in water treatment, Water Res. 33 (1999) 1049-1053.

[7] L.S. Downing, R. Nerenberg, Kinetics of microbial bromate reduction in a hydrogen-oxidizing, denitrifying biofilm reactor, Biotechnol. Bioeng. 98 (2007) 543-550.

[8] A.N. Davidson, J. Chee-Sanford, H.Y. Lai, C.-h. Ho, J.B. Klenzendorf, M.J. Kirisits, Characterization of bromate-reducing bacterial isolates and their potential for drinking water treatment, Water Res. 45 (2011) 6051-6062.

[9] M.J. Kirisits, V.L. Snoeyink, Reduction of bromate in a BAC filter, J. Am. Water Works Ass. 91 (1999) 74-84.

[10] M.J. Kirisits, V.L. Snoeyink, H. Inan, J.C. Chee-Sanford, L. Raskin, J.C. Brown, Water quality factors affecting bromate reduction in biologically active carbon filters, Water Res. 35 (2001) 891-900.

[11] Y.S. Pei, Optimization of Ozonation Process for Treating Bromide-Bearing Source Water and the Control of Bromate, Research Center for Ecoenvironmantal Sciences, Beijing, 2007, pp. 75-79.

[12] C.Zhao, L. Ruan, Biodegradation of Enteromorpha prolifera by mangrove degrading micro-community with physical-chemical pretreatment, Appl. Microbiol. Biotechnol. 92 (2011) 709-716.

[13] S. Yan, K. Miyanaga, X.-H. Xing, Y. Tanji, Succession of bacterial community and enzymatic activities of activated sludge by heat-treatment for reduction of excess sludge, Biochem. Eng. J. 39 (2008) 598-603.

[14] Q. Yang, F.E. Angly, Z. Wang, H. Zhang, Wastewater treatment systems harbor specific and diverse yeast communities, Biochem. Eng.J. 58-59(2011)168-176.

[15] H. Khoshdast, H. Abbasi, A. Sam, K.A. Noghabi, Frothability and surface behavior of a rhamnolipid biosurfactant produced by Pseudomonas aeruginosa MA01, Biochem. Eng. J. 60 (2012) 127-134.

[16] P.D. Schloss, S.L. Westcott, T. Ryabin, J.R. Hall, Introducing mothur: opensource, platform-independent, community-supported software for describing and comparing microbial communities, Appl. Environ. Microbiol. 75 (2009) 7537-7541.

[17] D.J. Reasoner, E.E. Geldreich, A new medium for the enumeration and subculture of bacteria from potable water, Appl. Environ. Microbiol. 49 (1985) $1-7$.

[18] A.E. Rotaru, C. Probian, H. Wilkes, J. Harder, Highly enriched Betaproteobacteria growing anaerobically with p-xylene and nitrate, FEMS Microbiol. Ecol. 71 (2010) 460-468.

[19] K.A. Berg, C. Lyra, K. Sivonen, L. Paulin, S. Suomalainen, P. Tuomi, J. Rapala, High diversity of cultivable heterotrophic bacteria in association of cyanobacterial water blooms, ISME J. 3 (2009) 314-325.

[20] R.M. Niemi, I. Heiskanen, R. Heine, J. Rapala, Previously uncultured Betaproteobacteria dominate in biologically active granular activated carbon (BAC) filters, Water Res. 43 (2009) 5075-5086.

[21] S.T. Khan, Y. Horiba, M. Yamamoto, A. Hiraishi, Members of the family Comamonadaceae as primary poly(3-Hydroxybutyrate-co-3Hydroxyvalerate)-degrading denitrifiers in activated sludge as revealed by a polyphasic approach, Appl. Environ. Microbiol. 68 (2002) 3206-3214.

[22] T. Sadaie, A. Sadaie, M. Takada, K. Hamano, J. Ohnishi, N. Ohta, K. Matsumoto, Y. Sadaie, Reducing sludge production and the domination of Comamonadaceae by reducing the oxygen supply in the wastewater treatment procedure of a food-precessing factory, Biosci. Biotechnol. Biochem. 71 (2007) 791-799.

[23] H. Rintala, M. Pitkäranta, M. Toivola, L. Paulin, A. Nevalainen, Diversity and seasonal dynamics of bacterial community in indoor environment, BMC Microbiol. 8 (2008) 1-13.

[24] S.R. Mueller-Spitz, G.W. Goetz, S.L. McLellan, Temporal and spatial variability in nearshore bacterioplankton communities of Lake Michigan, FEMS Microbiol. Ecol. 67 (2009) 511-522.

[25] K.D. McMahon, M.A. Dojka, N.R. Pace, D. Jenkins, J.D. Keasling, Polyphosphate kinase from activated sludge performing enhanced biological phosphorus removal, Appl. Environ. Microbiol. 68 (2002) 4971-4978.

[26] J.D. Coates, U. Michaelidou, R.A. Bruce, S.M. O'Connor, J.N. Crespi, L.A. Achenbach, Ubiquity diversity of dissimilatory (per)chlorate-reducing bacteria, Appl. Environ. Microbiol. 65 (1999) 5234-5241.

[27] H. Zhang, M.A. Bruns, B.E. Logan, Perchlorate reduction by a novel chemolithoautotrophic, hydrogen-oxidizing bacterium, Environ. Microbiol. 4 (2002) 570-576.

[28] M. Fahrbach, J. Kuever, R. Meinke, P. Kämpfer, J. Hollender, Denitratisoma oestradiolicum gen. nov., sp. nov., a 17ß-oestradiol-degrading, denitrifying betaproteobacterium, Int. J. Syst. Evol. Microbiol. 56 (2006) 1547-1552.

[29] L.A. Achenbach, R.A. Bruce, U. Michaelidou, J.D. Coates, Dechloromonas agitata N.N. gen., sp. nov. and Dechlorosoma suillum N.N. gen., sp. nov., two novel 
environmentally dominant (per)chlorate-reducing bacteria and their phylogenetic position, Int. J. Syst. Evol. Microbiol. 51 (2001) 527-533.

[30] S.K. Chaudhuri, S.M. O'Connor, R.L. Gustavson, L.A. Achenbach, J.D. Coates, Environmental factors that control microbial perchlorate reduction, Appl. Environ. Microbiol. 68 (2002) 4425-4430.

[31] A. Assuncao, M. Martins, G. Silva, H. Lucas, M.R. Coelho, M.C. Costa, Bromate removal by anaerobic bacterial community: mechanism and phylogenetic characterization, J. Hazard. Mater. 197 (2011) 237-243.

[32] K. Leung, Y. Chang, Y. Gan, A. Peacock, S. Macnaughton, J. Stephen, R. Burkhalter, C. Flemming, D. White, Detection of Sphingomonas spp. in soil by PCR and sphingolipid biomarker analysis, J. Ind. Microbiol. Biotechnol. 23 (1999) $252-260$.

[33] J.K. Fredrickson, D.L. Balkwill, M.F. Romine, T. Shi, Ecology, physiology, and phylogeny of deep subsurface Sphingomonas sp., J. Ind. Microbiol. Biotechnol. 23 (1999) 273-283.

[34] J. Fredrickson, D. Balkwill, G. Drake, M. Romine, D. Ringelberg, D. White, Aromatic-degrading Sphingomonas isolates from the deep subsurface, Appl. Environ. Microbiol. 61 (1995) 1917-1922.

[35] D.J. Muller, W.A. Engel, Conformational change of the hexagonally packed intermediate layer of Deinococcus radiodurans monitored by atomic force microscopy, J. Bacteriol. 178 (1996) 3025-3030. 